\title{
Особливості когнітивного компоненту економічної культури підлітків
}

\begin{abstract}
Анотація. B статті аналізуються особливості пізнання підлітками економічних иінностей в системі особистої власності. Показані основні тендениії ускладнення образу особистої власності у підлітків. Зокрема, аналізуються особливості уявлень підлітків про себе як суб 'єктів відносин особистої власності та про особисті блага як об'єкти привласнення. Співвіднесені з моральними цінностями, иі уявлення становлять когнітивну основу економічної культури підлітків. Аналізується міра когнітивної складності образу особистої власності у підлітків порівняно з молодшими школярами. Порівнюється поінформованість підлітків і молодших школярів про сутність, розмаїття тих економічних благ, якими оперує суб'єкт господарської діяльності.

Ключові слова: особистість, економічна культура особистості, підліток, соиіальне пізнання, особиста власність.
\end{abstract}

Постановка проблеми. Особливості соціально-економічного простору сучасного суспільства зумовлюють вимоги до економічної культури українців. Коли декларуються орієнтації на вільний ринок, конкуренцію, право на приватну власність, одночасно практикується монополізм в цілих галузях економіки, «ручне управління» бюджетом, мораторій на продаж землі тощо. В таких умовах ціннісного хаосу процес економічної соціалізації молоді може набути своєрідних, викривлених і небажаних форм. Тому великий науковий та практичний інтерес становить вивчення тенденцій, яких набуває процес розвитку економічної культури української молоді. Зокрема, гостро стоїть питання особливостей становлення економічної культури особистості, з одного боку, ще за відсутності досвіду регулярних економічних відносин, з іншого боку, за набуття першого досвіду трудових, торгівельних, інвестиційних відносин. Йдеться про підлітковий етап становлення економічної культури особистості.

Аналіз останніх досліджень 3 проблеми. Поняття «економічної культури особистості» тільки віднедавна введене в тезаурус психологічної науки. Вітчизняними психологами $[1 ; 2 ; 5 ; 6 ; 8]$ економічна культура вивчається як результат і показник економічної соціалізованості особистості.
При цьому економічна культура підлітків як соціально-психологічний феномен вивчалась досить фрагментарно, в окремих аспектах. Щоправда, слід відзначити існування праць психологів, в яких висвітлено результати вивчення окремих складових економічної свідомості підлітків [1-4; 10; 11], сфокусовані переважно на іiі монетарному аспекті (на ставленні до кишенькових грошей та його соціалізуючій ролі). Але монетарна соціалізація - це тільки одна $з$ складових процесу становлення економічної культури підлітка. Оскільки останній протікає у більш широкому контексті - у відносинах власності $[2 ; 6 ; 7]$, - то важливим для розуміння багатьох його закономірностей у підлітків $є$ вивчення особливостей становлення окремих його компонентів (пізнавального, афективного, конативного) у просторі відносин особистої власності.

Метою даної статті $\epsilon$ висвітлення результатів аналізу особливостей пізнавального компоненту економічної культури підлітків, тобто уявлень, наявних знань про економіку і відносини, які її конституюють.

3 одного боку, системотворчим чинником будь-якої економіки є стосунки між людьми, що складаються 3 привласнення матеріальних чи духовних благ [6;7]. 3 іншого боку, особиста економіка дитини 
заснована на її можливостях володіти, розпоряджатися і користуватися особистими благами (своїм життям, тілом, долею, особистими речами, ідеями, витівками тощо) $[5 ; 6]$. Тому вивчення закономірностей формування економічної культури підлітків неможливе поза дослідженням змісту наївних знань та уявлень підлітків про особисту власність.

Виклад основного матеріалу. На основі філософського підходу до трактування культури, структурно-функціональної концепції економічної соціалізації особистості $[5 ; 6 ; 8]$, інтеріндивідного $[6 ; 8]$ та системного підходів до становлення економічної культури особистості [5-8], а також концепції психологічного ставлення [5] нами розроблена концептуальна модель становлення економічної культури школярів у системі особистої власності, на яку ми спиратимемось у подальших міркуваннях. Згідно з останньою, в підлітковому віці продовжують оформлятись психологічні основи економічної культури особистості - триває дорослішання особистості, в тому числі у сфері економіки. Останне виражається у оформленні психолого-економічних якостей, що забезпечать уже сьогодні, а не в дорослому житті, гармонійне включення у ринкові відносини. Йдеться про цінності підприємливості, система яких імпліцитно несе в собі нормативний для ринкової економіки образ «людини економічної» [5; 6; 8].

Для підлітка цінності підприємливості апробуються і засвоюються у відносинах особистої власності. При цьому під особистою власністю розуміємо відносини між людьми з розподілу обмежених життєвих благ, що особисто притаманні, належні виключно одному суб'єктові - ix власникові, — та здатні задовольняти його матеріальні й духовні потреби. Особиста власність обгрунтовується нами [5] як система відносин привласнення-відчуження суб'єктами певних життєвих благ, в результаті чого останні набувають статусу об'єкта безумовного особистого моноволодіння. Це означає, що привласнене благо особистість називає «своїм», ним володіє i самостійно приймає рішення про його подальшу «долю»: щодо користування та розпорядження ним. Саме в таких акціях привласнення собі - відчуження від себе підліток освоює і апробує економічні ролі підприємливої людини (підприємця чи найманого працівника, користувача банківськими послугами, благодійника тощо), яка обізнана на раціональних способах оперування грішми, способах заробітку. В цьому віці особисті блага (скарби, колекції, ідеї тощо) набувають особливої цінності як такі, що починають символізувати соціальний статус у спільноті однолітків. Особливо актуальним стає усвідомлення цінності цивілізованих, суспільно прийнятних способів здобуття матеріальних ресурсів для того, щоб отримати бажане благо.

Спробуємо підтвердити чи спростувати хоч частку наведених припущень, проаналізувавши результати пізнання підлітками економічних цінностей в системі особистої власності. У опитуванні, проведеному в 2013-2014 pp. у ЗОШ №329 та 274 Києва, взяли участь 80 учнів 7-8-х класів (віком 13-14 років).

Аналіз відповідей на питання «що в житті ти називаєш особисто своїм, про що можеш сказати: «це - особисто моє?» показав особливості пізнання особистої власності підлітками. Для аналізу змін, яких зазнає пізнавальний компонент економічної культури на підлітковому етапі соціалізації порівняємо зміст образу «особисто моє» підлітків і молодших школярів. Згідно $з$ таблицею 1, можемо констатувати зростання 3 віком когнітивної складності досліджуваного образу: 3254 характеристик у молодших школярів до 423 - у підлітків. 
Таблиияя 1

Смислові одиниці, виявлені в образі «особисто моє» в групах порівняння

\begin{tabular}{|c|c|c|}
\hline \multirow{2}{*}{ Смислові одиниці } & \multicolumn{2}{|c|}{ Кількість характеристик в групах порівняння } \\
\hline & Серед молодших школярів & Серед підлітків \\
\hline Матеріальні речі: & 234 & 327 \\
\hline 1) Апаратура & 15 & 89 \\
\hline 2) Побутові речі & 51 & 45 \\
\hline 3) «Мої речі» & & 3 \\
\hline Шкільне приладдя, книги & 85 & 42 \\
\hline 5) Особистий одяг & & 37 \\
\hline Речі віртуальні & & 2 \\
\hline 7) Тіло, частини тіла & & 48 \\
\hline 8) Спортивне приладдя & & 2 \\
\hline 9) Іграшки & 40 & 10 \\
\hline 10) Їжа (смачне, цукерки, тістечка) & 5 & \\
\hline Економічні цінності: & 38 & 49 \\
\hline 11) Нерухомість & 38 & 45 \\
\hline 12) Гроші & & 4 \\
\hline Психологічні ресурси: & & 96 \\
\hline 13) Ідентифікація з економічними ролями & & 38 \\
\hline 14) Психологічні процеси & & 21 \\
\hline 15) Особисті уміння, таланти & & 25 \\
\hline Трансцендентні цінності & & 12 \\
\hline Всього: & 254 & 423 \\
\hline
\end{tabular}

3 таблиці 1 видно, що образ «особисто моє» у підлітків закономірно в когнітивному плані складніший, ніж у молодших школярів. Привертає увагу те, що уявлення підлітків про особисту власність більш насичені економічними категоріями. Ускладнення образу відбувається за рахунок усвідомлення матеріальних особистих речей як належних собі (переважно через усвідомлення можливостей самопрезентації і самовираження в одязі, апаратурі, віртуальних речах та нерухомості, через пізнання своєї тілесності, особистих грошей), ідентифікації з широким колом економічних ролей та усвідомлення своїх умінь і талантів, зокрема досягнень у спорті, психологічних процесів як ресурсів власника. Таким чином, можна стверджувати, що підлітки обізнані як про широке коло матеріальних, так і духовних цінностей, на які орієнтуються у своїй особистій економіці.

Більш точно з'ясувати, як трансформується образ особистої власності в уяв- леннях підлітків у контексті відносин, пов'язаних з господарською діяльністю, дозволив експеримент із привнесенням у завдання економічного контексту. Учням було запропоновано пофантазувати і написати невелику казку про особисті речі, майно, гроші людини, яка має своє господарство. За основу контент-аналізу були взяті показники особливостей пізнання особистої власності в економічному контексті, а саме уявлення про економічні блага у житті особистості: їх джерела, форми існування; уявлення про головного героя казки як проекція уявлень про себе як власника [7]. В результаті переважну більшість (408 характеристик) смислових одиниць в образі власності людини, що має своє господарство, становлять ті, що стосуються психологічних ресурсів особистості. Хоча слід зауважити про майже співставний з попереднім показник згадування матеріальних речей (361 характеристика), див. табл. 2. 
Смислові одиниці в образі особистої власності підлітків

Таблиияя 2

в контексті господарської діяльності

\begin{tabular}{|c|c|c|}
\hline \multicolumn{2}{|r|}{ Смислові одиниці } & Кількість одиниць \\
\hline \multicolumn{2}{|r|}{ 1. Матеріальні речі: } & 361 \\
\hline 1) & Територія (королівство, планета, місто щасливих людей) & 56 \\
\hline 2) & $\begin{array}{l}\text { Економічні цінності: нерухомість, рухоме майно, активи, гроші, по- } \\
\text { бутові речі, таємничі джерела благ, скарби }\end{array}$ & 205 \\
\hline 2. & Психологічні ресурси: & 408 \\
\hline 3) & $\begin{array}{l}\text { Ідентифікація з економічною роллю: банкіра, власника, споживача, } \\
\text { працівника, бідняка, багатія, політика }\end{array}$ & 43 \\
\hline 4) & Ідентифікація з роллю в родині (дитина, сирота, мама) & 8 \\
\hline 5) & Ідентифікація зі статтю (хлопчик, дівчинка, гарна дівчина) & 9 \\
\hline 6) & Типи економічних відносин: фінансові, трудові & 18 \\
\hline 7) & Способи оперування матеріальними цінностями & 108 \\
\hline 8) & Моральні якості (добро, дружелюбність, щедрість, піклування) & 11 \\
\hline 9) & Моральнісна оцінка особистих благ (позитивна-негативна) & 27 \\
\hline 10) & Емоційне ставлення до матеріальних благ & 80 \\
\hline & Орієнтованість на соціально-економічні зв'язки & 73 \\
\hline & Всього: & 848 \\
\hline
\end{tabular}

Отже,природно,щопідлітки,порівняноз молодшими школярами, більш поінформовані про сутність, розмаїття тих економічних благ, якими оперує суб'єкт господарської діяльності. Привертає увагу той факт, наскільки підлітки просуваються у пізнанні власних, специфічних для суб'єкта господарювання, економіко-психологічних ресурсів (ідентифікації з основними економічними ролями $(\mathrm{p}<=0,001)-$ бідняка-багатія (20 характеристик), банкіра (4), працівника (6), обізнаності у трудових (7) та фінансових (9) типах економічних відносин ( $<<=0,01)$ і обізнаності в основних способах оперування економічним благами ( $\mathrm{p}<=0,001)$ - накопичення і заощадження (17), утриманство (20), обмін (24), заробіток (8), - у позитивній моральнісній оцінці економічних благ $(21, \mathrm{p}<=0,01)$ та в орієнтованості на соціально-економічні зв'язки (наявність діалогів та живих істот, що взаємодіють з іншими - 73 характеристики, $\mathrm{p}<=0,001)$.

Виявлено, що підлітки приблизно 3 однаковою частотою обмірковують i джерела надходження економічних благ (грошей, багатства, своєї справи, бізнесу) (в 59\% згадувань), і сфери їх витрат (у $50 \%$ ). На фоні цих результатів цікавими i неоднозначними є висновки О. Горбачо- вої та А. Купрейченко про виявлену на вибірці дорослих тенденцію: більш, ніж 50\% асоціацій присвячені тому, як витратити матеріальні блага (гроші), і лише $15 \%$ стосуються способів їх отримання [7, с. 457].

Щоправда, цікавим виявився факт міфологізації підлітками джерел надходження доходів: переважна більшість (окрім згадувань про батьків, заробіток та посилання на нечесні способи привласнення благ) джерел надходження - це загадкові магічні обставини («чарівний гаманець», «грошове дерево», чарівна поличка в шафі» і т.п.). Можемо припускати, з одного боку, що поінформованість підлітків про економіку є недостатньою, багато явищ в економіці є чи незрозумілими, чи такими, що не потрапляють у поле уваги учнів середньої школи й не є предметом осмислення. 3 іншого ж боку, якщо дотримуватись тези про те, що підлітки вже мислять майже тими економічними категоріями, що й дорослі, то неабияке значення серед мотивів втаємничувати джерела доходів може відігравати сімейна практика не посвячувати сторонніх у власні матеріальні справи. В усякому разі, виявлений факт потребує пояснень і більш детального дослідження. Очевидно, наше дослідження не підтвердило думку окремих економічних психо- 
логів [10; 12] про те, що у 13-14 років система уявлень школярів про світ економіки майже відповідає системі уявлень дорослої людини.

Підводячи підсумки, зазначимо, що уявлення про особисті блага у підлітків в когнітивному плані складніші, ніж у молодших школярів. Економічний зміст останніх ускладнюється завдяки усвідомленню можливостей для самопрезентації та самовираження через одяг, особисті віртуальні та матеріальні речі, пізнанню своєї тілесності, ідентифікації з більш широким, ніж у молодших школярів, колом економічних ролей та усвідомленню власних психологічних ресурсів (умінь і талантів) для реалізації своїх планів як власника.
Підтверджена провідна роль кишенькових грошей у соціалізації підлітків як суб'єктів господарської діяльності. Порівняно 3 молодшими школярами, підлітки більш поінформовані про сутність, розмаїття тих економічних благ, якими оперує суб'єкт господарської діяльності. Підлітки орієнтуються на такі основні способи оперування матеріальними цінностями, як заощадження, обмін, витрачання, заробіток.

Перспективним, на наш погляд, у дослідженні особливостей образу особистої власності в учнів основної школи може стати вивчення вікових закономірностей розвитку не тільки когнітивної, але й афективної та конативної складових економічної культури підлітків.

\section{Список використаних джерел:}

1. Авер'янова Г.М. Особливості соціалізації молоді в умовах трансформації суспільства / Г. М. Авер'янова, Н. М. Дембицька, В. В. Москаленко. - К. : «ППП», 2005. - 307 с.

2. Антонова 3.О. Соціально-психологічні особливості економічної соціалізації підлітків : автореф. дис. ... канд. психол. наук : 19.00.05. / 3. О. Антонова // Інститут психології імені Г.С. Костюка НАПН України. - Київ, 2011. - 19 с.

3. Буренина С. Ю. Влияние денег на процессы социализации современных подростков : автореф. дисс. ... канд. психол. наук : спец. 13.00.01 «Общая педагогика» / С. Ю. Буренина. - СПб., 2000. - 14 с.

4. Годфри Дж. Как научить ребенка обращаться с деньгами / Джолайн Годфри; Пер. с англ. - М. : Издательство «Добрая книга», 2006. - 224 с.

5. Дембицька Н. М. Становлення основ економічної культури школяра у просторі шкільної освіти / Н. М. Дембицька // Збірник наукових праць: філософія, соціологія, психологія. - Івано-Франківськ : Вид-во ДВНЗ «Прикарпатський національний університет імені Василя Стефаника, 2015. - Вип. 20, ч. 1. - С. 74-82.

6. Економічна соціалізація молоді: соціально - психологічний аспект: наукове видання / І. В. Білоконь, Н. М. Дембицька, І. К. Зубіашвілі та ін. ; заг. ред. В.В. Москаленко. — К. : Український центр політичного менеджменту, 2008. - 336 с.

7. Журавлев А. Л. Экономическое самоопределение: Теория и змпирические исследования / А. Л. Журавлев, А.Б. Купрейченко. - М. : Изд-во Института психологии РАН, 2007. $-480 \mathrm{c}$.

8. Москаленко В.В. Соціалізація особистості : монографія / В.В. Москаленко. — К. : Фенікс, 2013. - $540 \mathrm{c}$.

9. Осорина М.В. Секретный мир детей в пространстве мира взрослых / М.В. Осорина. - СПб. : Питер, 2008. - 304 с.

10. Уэбли П. Понимание детьми економических явлений / П. Уэбли // Проблемы экономической психологии / отв. ред. А. Л. Журавлев, А.Б. Купрейченко. - М. : ИП РАН, 2005. — T. 2. - C. 146-177.

11. Фенько А.Б. Дети и деньги: особенности экономической социализации / А.Б. Фенько // Вопросы психологии. — 2000. - №2. - С. 94-101.

12. Фернам А. Деньги. Психология денег и финансового поведения / А. Фернам, М. Аргайл. - СПб. : Прайм-ЕВРОЗНАК, 2005. - 352 с.

Аннотация. $B$ статье анализируются особенности познания подростками экономических иенностей в системе личной собственности. Показаны основные тенденции осложнения образа личной собственности у подростков. В частности, анализируются особенности представлений подростков о себе как о субъектах отномений личной собственности и о личном благе как об объектах присвоения. Соотнесены с нравственными иенностями, эти представления соста- 
вляют когнитивную основу экономической культуры подростков. Анализируется степень когнитивной сложности образа личной собственности у подростков по сравнению с младиими школьниками. Сравнивается осведомленность подростков и младиих школьников о сущности, разнообразие тех экономических благ, которыми оперирует субъект хозяйственной деятельноcmu.

Ключевые слова: личность, экономическая культура личности, подросток, соччиальное познание, личная собственность.

Abstracts. The article is devoted to actual problem of studying the content of the cognitive component of teenagers' economic culture. In particular peculiarities of teenagers' representations of themselves as actors of personal property relations and personal benefits as objects of appropriation are analyzed. Related to moral values, these ideas are cognitive basis of economic culture of teenagers.

The paper shows that the representation of teenagers' personal benefits in cognitive terms are more complex in comparison with primary school pupils. The economic content of the representations of teenagers 'personal benefits is complicated due to the recent awareness of opportunities for self-expression through the clothing, personal virtual and material things. Also it takes place through the knowledge of their physicality, identification with a wider area of economic roles and awareness of their own psychological resources (skills and talents) for realization of claims as proprietor.

It is confirmed the leading role of pocket money in the economic socialization of adolescents. In comparison with primary school pupils, teenagers are more aware of the nature, variety of economic benefits of the economic actor. Teenagers are guided by the following main ways of operation by material values like savings, exchange, expenditure, income.

The perspective way in researching of representations' features of personal property may be the agerelated patterns of development not only cognitive but also affective and behavioral components of the teenagers' economic culture.

Keywords: personality, economic culture of personality, teenager, social cognition, personal property. 